
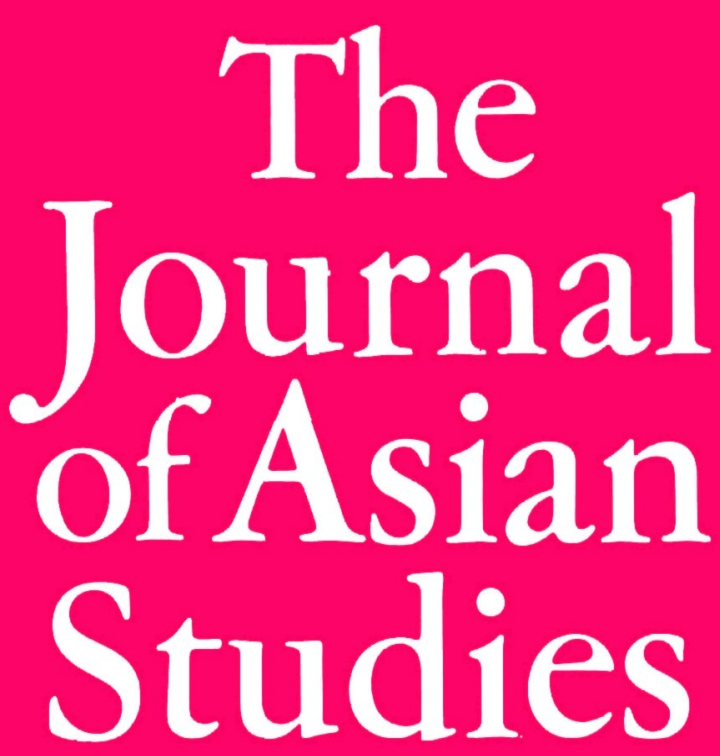

VOLUME 46

NUMBER 2

MAY 1987

PUBLISHED BY

THE ASSOCIATION

FOR ASIAN STUDIES, INC.

UNIVERSITY OF

CALIFORNIA PRESS 


\section{Asian Studies on microfiche}

A few IDC projects

South Asia

Census of India, 1872-1951

District Gazetteers of British India

Art and Archaeology

Selections from the Records of India

Rare Serials and books from the IOL

New General Catalogue (1986)

\section{South-East Asia}

Indonesian Monographs and Serials Memories van Overgave

(Dutch East Indies)

Vietnamese Law

Indonesian Communist Party

Documents and Serials

\section{East Asia}

Rare Japanese works

(Von Siebold Collection)

Rare Chinese works

(Van Gulik Collection)

Protestant Missionary works in Chinese

New General Catalogue (1986)

For full information, free catalogues and details of discounts on microfiche readers, write to:

IDC AG, Industriestrasse 7 $6300 \mathrm{Zug}$, Switzerland

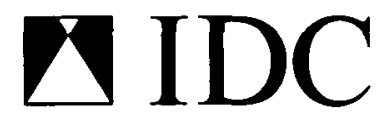

\section{Microform Publishers}

\section{AAS ANNUAL MEETING}

The Fortieth ANNUAL MEETING of the ASSOCIATION FOR ASIAN STUDIES will be held at the San Francisco Hilton and Tower, San Francisco, California, March 25-27, 1988

The Forty-first ANNUAL MEETING of the ASSOCIATION FOR ASIAN STUDIES will be held at the Washington Hilton and Towers, Washington, DC, March 17-19, 1989

Expected attendance: 2000

For further information, write: Association for Asian Studies 1 Lane Hall, University of Michigan, Ann Arbor, MI 48109

(313) $665-2490$ 


\section{The \\ Journal \\ of Asian \\ Studies}

Vol. 46, No. 2 MAY 1987

\section{CONTENTS}

\section{Abstracts}

253 Editor's Note

\section{Articles}

255 The Cult of Mount Atago and the Atago Confraternities

ANNE-MARIE BOUCHY

279 Party, Society, and Local Elite in the Jiangxi Communist

STEPHEN C . AVERIL Movement

\section{Giving in Asia-A Symposium}

305 Introduction

MARY ELIZABETH BERRY

309 Benevolent Societies: The Reshaping of Charity During the Late Ming and Early Ch'ing

JOANNA F. HANDLIN SMITH

339 From Tribute to Philanthropy: The Politics of Gift Giving in a DOUGLAS E. HAYNES Western Indian City

361 Religious Gifting and Inland Commerce in Seventeenth-Century South India

DAVID WEST RUDNER

\section{Communications to the Editor}

381 On a Review of Centers, Symbols, and Hierambies: Essays on the Classical States of Soutbeast Asia

MICHAEL AUNGTHWIN

Articles in The Joumal of Asian Studies represent neither the views of the Association for Asian Studies nor those of the Editors. The Editor is responsible for the final selection of the content of the Journal and reserves the right to reject any material deemed inappropriare for publication. Responsibility for opinions expressed and for the accuracy of facts published in articles rests solely with the individual authors.

COPYRight (C) 1987 by the Association for AsIan Studies, INC. All Rights Reserved

Requests for permission to reprint should be directed to University of California Press, Journals Department. The Journal is indexed in the Social Sciences $\&$ Humanities Index and Book Review Index and abstracted in Hisforical Abstracts and America: History and Life. It is also available on film through University Microfilms, Ann Arbor, Michigan 48109. 


\section{Book Reviews}

\section{Asia General}

\section{China and Inner Asia}

386 BONNER, Wang Kuo-wei: An Intellectual Biography

VERA SCHWARCZ

387 Dietrich, People's Cbina: A Brief History

JAMES E. SHERIDAN

388 ELman, From Philosophy to Philology: Intellectual and Social Aspects of Change in Late Imperial China

JEROME B. GRIEDER the Confucian Canon

KWONG-LOI SHUN

The Joxmal of Asian Studies, known until September 1956 as the Far Eastem Quarterly, is published by the Association for Asian Studies (formerly The Far Eastern Association) in February, May, August, and November. The annual institutional subscription rate for the Journal (including the Bibliography of Asian Studies) is $\$ 80$, postage included. Single issues of the Journal and Bibliograpby published after February 1966 are available through the Secretariat of the Association. Issues published prior to 1966 may be purchased from A.M.S. Reprints, 56 E. 13th Streer, New York, New York 10003

Membership in the Association for Asian Studies, a scholarly, nonpolitical and nonprofit organization, is open to all persons interested in Asia and the scholarly study of Asia. Annual membership dues are \$35 for Regular members, $\$ 15$ for Retired members, and \$15 for Student members. Student membership is restricted to full-time students for a maximum of five years. Regular, Retired, and Student members receive The Jowrnal of Asian Studies and the Asian Studies Newsletter.

All correspondence regarding membership, subseriptions, advertising, reprints, or business should be addressed to the SecretaryTreasurer or Administrative Officer, Association for Asian Studies, Inc., Room 1, Lane Hall, University of Michigan, Ann Arbor, Michigan 48109.

The editor welcomes preliminary inquiries about manuscripts for possible publication in The Journal of Asian Studies. Completed manuscripts should be sent to the editor, Thomas R. H. Havens, JAS, Connecticut College, New London, Connecticut 06320. Please submit four copies. Evr ryching should be double-spaced, including extracts, notes, and references. Because manuscripts cannot be returned, please do not send the original. Consult recent issues of the Journal as a guide to the format for source citations, notes, and references. Footnotes should be limited, typed separately at the end of the text, and follow the style recommended in sections 15.4 through 15.35 of The Chicago Manual of Sithle, 13th ed. (Chicago: University of Chicago Press, 1982). All manuscripts submitted to the JAS are expected not to have been published elsewhere and not to be under review for possible publication elsewhere. Manuscripts, including notes, should not be more than 40 pages in length.

The Joumals production arrangements with the University of California Press make it possible to illustrate articles with tables, figures, and black-and-white photographs more easily than in the past. Authors in all fields are encouraged to submit illustrations along with their manuscripts. (Photos of record or photocopies are acceptable for first review and should accompany the manuseript at original submission.) Authors who wish to illustrate their articles with photographs must provide black-and-white glossy prints of good quality, focus, contrast, and surface condition at the time of delivery of their manuscripts for copyediting. Final acceptance of illustrated manuscripts will be conditional on receiving good quality photographs for reproduction. Please provide a separate typewritten, double-spaced list of captions and legends for all illustrations, keyed by number to each figure or photograph, including all necessary credit and permission lines. Authors are responsible for securing and paying for permission to use illustrative material. Do not write anything on the verso of photographs; do not paste photographs to sheets of paper. Identify each photo by typing the first words of its caption on a stick-on label, then affix the label gently but firmly to the verso of the photo. Photographs will be returned after publication.

Books for review and correspondence concerning reviews should be sent to the appropriate editor. Books on Asia General should be sent to the office of the editor. Books on Cbina and Inner Asia should be sent to Dr. Joanna F. Handlin Smith, Fairbank Center for East Asian Research, 1737 Cambridge Street, Harvard University, Cambridge, MA 02138; books on Japan should be sent to Professor Andrew Gordon, Asian/Pacific Studies Institute, 2111 Campus Drive, Duke University, Durham, NC 27706; books on Korea should be sent to Dr. Laurel Kendall, Department of Anthropology, American Museum of Natural History, Central Park West at 79th Street, New York, NY 10024; books on South Asia should be sent to Dr. Paul Greenough, Department of History, 205 Shaeffer Hall, Universiry of lowa, lowa City, IA 52242; books on Southeast Asia should be sent to Professor Robert W. Hefnet, Department of Anthropology, Boston University, Boston, MA 02215.

Second class postage paid at Ann Arbor, Michigan and at additional second class entry. POSTMASTER: Send address changes to The Association for Asian Studies, 1 Lane Hall, University of Michigan, Ann Arbor, Michigan 48109. 

in Ostasien: Festscbrift für Hans Steininger [Religion and philosophy in East Asia: Hans Steininger festschrift]

\section{Japan}

401 BORgeN, Sugawara no Micbizane and the Early Heian Court Roban Koda

417 Nijima, Niijima Jō Zensbū: The Complete Works of Joseph Hardy Neesima. Vol. 6: Letters in English the Organization of Trade

\section{Soutb Asia}



Nortbwest Nepal

433 FISHER, The Wisdom of the Heart: $A$ Study of the Works of Mulk Raj Anand

DAVID HOLMBERG

434 FORSTER; HEINE (ed.), The Hill of Devi and Otber Indian Writings

435. HOLMSTROM, Industry and Inequality: The Social Antbropology of Indian Labour

441 KuKrejA, Military Intervention in Politics: A Case Study of Pakistan

436 Lebra-Chapman, The Rani of Jbansi: A Study in Female Heroism in India

438 LIDDLE and JOSHI, Daughters of Independence: Gender, Caste, and Class in India

439 PERERA, New Dimensions of Social Stratification in Rural Sri Lanka

440 RAMANUJAM, Indian Labour Movement

441 RIzVI, The Military and Politics in Pakistan, 1947-86

442 THAPAR, From Lineage to State: Social Formations in the Mid-First Millennium B.C. in the Ganga Valley

444 wiluams, A New Face of Hinduism: The Suaminarayan Religion

MARK JUERGENSMEYER

\section{Soutbeast Asia}

446 BANKs, Malay Kinship

MICHAEL G. PELETZ

448 BonNeff, Pérégrinations javanaises: Les voyages de R. M. A. Purwa Lelana-une vision de Java au XIX siècle (c. 1860-1875)

449 HEFNER, Hindu Javanese: Tengger Tradition and Islam

JAMES L. PEACOCK

450 HOOKER, Islamic Law in Soutb-East Asia

PAUL W. VAN DER VEUR

451 HUfFMAN, Bibliography and Index of Mainland Southeast Asian Languages and Linguistics

JAMES A. MATISOFF

453 ISHII; HAWKES (trans.), Sangha, State, and Society: Thai Buddhism in History

ELLISON B. FINDLY 
454 KAUR, Bridge and Barrier: Transport and Communications in Colonial Malaya, 1870-1957

456 KUMar, The Diary of a Javanese Muslim: Religion, Politics, and the Pesantren, 1883-1886

457 MARTEN (ed.), Traditional Agriculture in Southeast Asia: A Human Ecology Perspective

459 MILNE and MAUZY, Malaysia: Tradition, Modernity, and Islam

460 PRIzzIn, Thailand in Transition: The Role of Oppositional Forces

462 SCOTT, Weapons of the Weak: Everyday Forms of Peasant Resistance

463 TRUONG-BUU-LAM, with MAI, New Lamps for Old:

The Transformation of the Vietnamese Administrative Elite

464 TRUONG-BUU-LAM, with MAI, Resistance, Rebellion, Revolution: Popular Movements in Vietnamese History

465 WILSON and HANKS (eds. and trans.), The Burma-Thailand Frontier over Sixteen Decades: Three Descriptive Documents

466 YOU and LIM (eds.), Singapore: Twenty-five Years of Development

467 YouNG, Shan Chrestomatby: An Introduction to Tai Māu Language and Literature

\section{Obituary}

469 LUTHER CARRINGTON GOODRICH (1894-1986)
J. NORMAN PARMER

DANIEL S. LEV

DANIEL T. SICULAR

RONALD PROVENCHER

CHRISTOPHER COURT

DANIEL S. LEV

NGUYEN THE ANH

NGUYEN THE ANH

LORRAINE GESICK

LINDA LIM

SAO SAIMÖNG MANGRĀI

C. MARTIN WILBUR 


\section{The Journal of Asian Studies}

\section{Connecticut College, New London, Connecticut 06320}

Editorial Staff. Editor: Thomas R. H. Havens, Connecticut College. Associate Editor: ANDREw J. Nathan, Columbia University. Manuscript Editor: BetSey Scheiner, University of California Press. Editorial Assistant: MARY Jo C. BALDwin, Connecticut College. Proofreader: BONNIE DEHLER, University of California Press. Assistant Editors: China and Inner Asia, Richard P. Madsen, University of California, San Diego; Japan, Helen Hardacre, Princeton University; Korea, LaURel Kendall, American Museum of Natural History; South Asia, Lawrence A. Babb, Amberst College; Southeast Asia, Clark J. Neher, Northern Illinois University. Book Review Editors: China and Inner Asia, JoANnA F. HaNDLIN SMITH, Harvard University, and WILLIAM A. JOSEPH, Wellesley College; Japan, ANDREW GORDON, Duke University; Korea, LaUrel Kendall, American Museum of Natural History; South Asia, Paul Greenough, University of lowa; Southeast Asia, ROBert W. Hefner, Boston University.

\section{The Association for Asian Studies, Inc.}

1 Lane Hall, The University of Michigan, Ann Arbor, Michigan 48109

Officers of the Association. President: RHOADs MURPHEY, University of Michigan; Vice President: ROBERT J. SMITH, Cornell University; Secretary-Treasurer: L. A. PETER GosLING, University of Michigan.

Board of Directors. President, Vice President, and Secretary-Treasurer; Past President: SUSANNE HOEBER RUDOLPH, University of Chicago. 1985-1988: JUDITH A. BERLING, Indiana University, Bloomington; MIKISO HANE, Knox College; RHOADS MURPHEY, University of Michigan; MaRia CRISTINa Blanc Szanton, Columbia University; Sylvia Jane Vatuk, University of Illinois, Chicago. 1986-1989: JUDITH BECKER, University of Michigan; ElEANOR M. HADLEY, University of Washington/George Washington University; MARY FAINSOD KATZENSTEIN, Cornell University; David N. KeIGHTLEY, University of California, Berkeley; LuCIAN W. PYE, Massachusetts Institute of Technology; THOMAs R. H. HAvens, Connecticut College. 1987-1990: Charles HIRSCHMAN, Comell University; Karen Leonard, University of California, Irvine; LYNN A. STRUVE, Indiana University, Bloomington; JANET A. WALKER, Rutgers University.

Executive Committee. President, Vice President, Past President, and Secretary-Treasurer; Chair, China and Inner Asia Council: MARy Rankin, Washington, D.C.; Chair, Northeast Asia Council: Patricia G. Steinhoff, University of Hawaii; Chair, South Asia Council: OWen M. LynCH, New York University; Chair, Sourheast Asia Council: MARIA Cristina Blanc Szanton, Columbia University; Chair, Council of Conferences: Fred R. VON DeR MEHDEN, Rice University.

Staff of the Association. Administrative Associate: CArol M. Hansen. Comptroller: CarOUINE HACKETT. Journal Advertising and Records Supervisor: CAROL J. KeLINGOS. Membership Secretary: DONNA AsHTON.

SPONSORING INSTITUTIONS:

The University of Michigan

Connecticut College 